\title{
ANALISIS PENGARUH KARAKTERISTIK INDIVIDU, KARAKTERISTIK PEKERJAAN DAN KARAKTERISTIK ORGANISASI TERHADAP KINERJA KARYAWAN PT. TRANS NUSANTARA BORNEO
}

\author{
Dayat Ikhsan Hajati \\ Email: diksan.poltek.ktb@gmail.com \\ Politeknik Kotabaru
}

\begin{abstract}
The aims of this research were 1) to analyze the significant effect of individual characteristics on employees' performance partially, 2) to analyze the significant effect of job characteristics on employees' performance partially, 3) to analyze the significant effect of organizational characteristics on employees' performance partially, 4) to analyze the significant effect of individual characteristics, job characteristics and organizational characteristics on employees' performance simultaneously. The types of research was causal research. The populations were employees at PT. Trans Nusantara Borneo (TNB), with 30 peoples as samples in this research and sampling technique uses saturated sampling technique. The method of data analysis used multiple regression analysis. The results of research showed that individual characteristics have insignificant effect on employees' performance partially. Job characteristics and organizational characteristics have significant effect on employees' performance partially. Individual characteristics, job characteristics and organizational characteristics have significant effect on employees' performance simultaneously.
\end{abstract}

Keywords: Individual Characteristics, Job Characteristics, Organizational Characteristics, Employees' Performance. 


\section{PENDAHULUAN}

Sumber Daya Manusia (SDM) memiliki peranan yang penting untuk menunjang aktivitas, kelangsungan, dan keberhasilan suatu organisasi. Sumber Daya Manusia yang biasanya disebut karyawan/karyawan memiliki potensi yang positif terhadap pencapaian visi, misi, tujuan dan sasaran organisasi atau perusahaan apabila dikelola dengan benar, sebaliknya akan menjadi beban apabila tidak dikelola dengan benar. Organisasi/perusahaan yang besar dan maju selalu memperhatikan dan berusaha untuk meningkatkan kinerja karyawan/karyawan karena kinerja yang optimal adalah faktor penentu tercapainya tujuan suatu organisasi/perusahaan. Meskipun suatu organisasi/perusahaan memiliki teknologi yang maju dan modal yang besar, hal itu belum menjamin tercapainya visi, misi, tujuan dan sasaran suatu organisasi/perusahaan tanpa ditunjang dengan sumber daya manusia berkualitas.

Penelitian ini mengambil objek pada PT. Trans Nusantara Borneo yang berlokasi di Desa Sekapung Kecamatan Pulau Sebuku Kabupaten Kotabaru, Kalimantan Selatan. PT. TNB adalah sebuah perusahaan yang bergerak di bidang kontraktor tambang batubara. PT. TNB memiliki 30 orang karyawan tetap. Untuk mencapai visi, misi dan tujuannya serta sasaran dibutuhkan kinerja yang baik dan optimal dari setiap karyawan. Dalam mengukur kinerja karyawan dapat dilihat melalui kualitas kerja, kuantitas kerja dan ketepatan waktu (Bernadin dan Russel: 1993).

Setiap karyawan mempunyai karakteristik yang berbeda-beda yang disebabkan oleh beberapa hal, misalnya latar belakang sikap, kemampuan, minat dan faktor lainnya dari karyawan itu sendiri. Keberagaman perilaku tersebut akan mempengaruhi jalannya kegiatan organisasi. Peningkatan kinerja karyawan dipengaruhi oleh beberapa faktor yang salah satunya seperti karakteristik individu karyawan, dimana karakteristik individu memiliki peran yang sangat penting dalam peningkatan kinerja karyawan. Sedangkan menurut Robbins (2003), indikator karakteristik individu meliputi sikap, minat, nilai dan kemampuan.

Selain karakteristik individu, karakteristik pekerjaan juga dapat mempengaruhi kinerja karyawan. Seorang karyawan membutuhkan keterampilan untuk menyelesaikan suatu tugas, keterampilan karyawan ditentukan oleh aktifitas yang dikerjakan dan setiap aktifitas yang berbeda membutuhkan keterampilan yang beragam. Karakteristik 
pekerjaan yang berbeda memerlukan keterampilan, identitas tugas dan otonomi yang berbeda pula. Menurut Hackman and Oldham (1980) dalam Ozbag, G.K, Ceyhun, G.C dan Gunduz, (2014:440), hasil kerja karyawan dipengaruhi oleh 5 dimensi karakteristik pekerjaan inti yaitu keragaman keterampilan, identitas tugas, signifikasi tugas, otonomi, umpan balik pekerjaan.

Keberhasilan organisasi dalam menjaga eksistensi dan mencapai keberhasilan dipengaruhi oleh kinerja perusahaan dan kinerja karyawannya, untuk mencapai kinerja yang diharapkan, karakteristik suatu organisasi juga memiliki peranan yang penting dalam mempengaruhi kinerja karyawan. Setiap karyawan dan organisasi harus memiliki komitmen yang kuat, hubungan yang baik antara karyawan satu dengan yang lain maupun karyawan dengan atasan. (Hellregel dan Slocum: 2006).

\section{TINJAUAN PUSTAKA}

\section{Karakteristik Individu}

Karakteristik merupakan suatu sifat yang khas, yang melekat pada seseorang atau suatu objek. Karakteristik yang akan diteliti dan dibahas dalam penelitian ini adalah karakteristik individu, karakteristik pekerjaan dan karakteristik organisasi. Karakteristik individu merupakan karakter seorang individu yang mempunyai sifat khas sesuai perwatakan tertentu. Stoner (1992) dalam Moses, dkk (2014:2) menyatakan bahwa karakteristik individu meliputi, minat, sikap dan kebutuhan yang dibawa seseorang kedalam situasi kerja. Sedangkan menurut Robbins (2003), indikator karakteristik individu meliputi sikap, minat, nilai dan kemampuan.

1) Sikap individu berasal dari hal - hal atau akibat - akibat yang berhubungan dengan perasaannya, seperti, senang atau suka terhadap suatu hal, baik yang berwujud maupun abstrak baik benda hidup ataupun benda mati.

2) Minat merupakan keiinginan dan kecenderungan seseorang untuk melakukan perilaku dan untuk berkembang dan maju dalam beraktifitas.

3) Nilai seseorang didasarkan pada pekerjaan yang memuaskan, dapat dinikmati, pengembangan intelektual dan waktu untuk keluarga.

4) Kemampuan adalah kapasitas sesorang karyawan dalam melakukan dan menyelesaikan tugas dan pekerjaannya baik secara mental maupun fisik. 


\section{Karakteristik Pekerjaan}

Karakteristik pekerjaan merupakan sifat tugas yang meliputi keanekaragaman tugas dan besarnya tanggung jawab yang diberikan kepada karyawan beserta umpan baliknya. Menurut Hackman and Oldham (1980) dalam Ozbag, G.K, Ceyhun, G.C dan Gunduz, (2014:440), hasil kerja karyawan dipengaruhi oleh 5 dimensi karakteristik pekerjaan inti yaitu :

1) Keragaman keterampilan adalah suatu tingkatan dimana pekerjaan membutuhkan variasi aktifitas yang berbeda dalam menyelesaikan pekerjaan yang melibatkan sejumlah keterampilan dan bakat yang berbeda dari karyawan.

2) Identitas tugas adalah suatu tingkatan dimana pekerjaan membutuhkan penyelesaian menyeluruh dan teridentifikasi pembagianya, oleh karena seseorang terlibat mengerjakan pekerjaan dari awal sampai akhir dengan hasil yang memungkinkan.

3) Signifikasi tugas adalah suatu tingkatan dimana pekerjaan adalah penting dan melibatkan kontribusi yang berarti terhadap organisasi atau masyarakat pada umumnya.

4) Otonomi adalah suatu tingkatan dimana pekerjaan memberikan kebebasan secara substansial, kemerdekaan dan keleluasaan dalam membuat schedule pekerjaan dan menentukan prosedur yang digunakan untuk menyelesaikan pekerjaan.

5) Umpan balik pekerjaan adalah suatu tingkatan dimana hasil aktifitas penyelesaian pekerjaan diperoleh langsung oleh karyawan dan informasi yang jelas mengenai seberapa baik pekerjaan telah dikerjakan.

\section{Karakteristik Organisasi}

Widanarni (2015) mendifinisikan karakteristik organisasi sebagai wadah dimana seluruh bagian - bagian terintegrasi menciptakan lingkungan kerja bagi tiap - tiap individu yang ada, didalamnya terdapat kebijakan, budaya atau kultur kerja. Ada tiga indikator untuk mengukur karakteristik organisasi menurut Hellregel dan Slocum (2006) antara lain :

1) Komitmen terhadap tujuan organisasi, yang berkaitan dengan keinginan yang kuat untuk tetap menjadi anggota organisasi, bersedia untuk berusaha mencapai tujuan organisasi dan kepercayaan serta menerima tujuan nilai - nilai organisasi. 
2) Hubungan dengan teman sekerja, yang berkaitan dengan hubungan persahabatan dengan rekan sekerja dan saling mendukung antar rekan kerja tersebut.

3) Hubungan dengan atasan, yang menyangkut bantuan teknis, bimbingan dan perhatian atasan terhadap karyawannya.

\section{Kinerja Karyawan}

Dalam mengukur kinerja karyawan Bernadin dan Russel (1993:382) mengungkapkan bahwa terdapat enam kriteria dalam menilai kinerja karyawan, dalam hal ini peneliti memakai 3 (tiga) kriteria yang sangat mendasar yaitu :

1) Kuantitas Kerja (Quantity) yaitu : merupakan kemampuan karyawan dalam menyelesaikan target pekerjaan yang ditetapkan sekolah, kemampuan karyawan dalam menyelesaikan pekerjaan melebihi target yang diberikan oleh sekolah.

2) Kualitas Kerja (Quality) yaitu : Ketelitian karyawan dalam menyelesaian suatu pekerjaan, banyaknya kesalahan hasil dalam setiap pekerjaannya, pelaksanaan pekerjaan sesuai dengan standar operasional yang ditentukan oleh sekolah

3) Ketepatan waktu (Timeliness) yaitu : kemampuan karyawan dalam menyelesaikan pekerjaan sesuai dengan waktu yang ditetapkan, kesediaan karyawan untuk melakukan pekerjaan lembur serta kemampuan karyawan dalam menyelesaikan tugas tambahan sesuai dengan waktu yang ditentukan sekolah.

\section{METODE PENELITIAN}

Dalam penelitian ini menggunakan jenis penelitian sebab akibat (causal research) dengan teknik pengambilan sampel menggunakan teknik sampling jenuh atau sensus. Maka dari itu, sampel yang diambil adalah seluruh karyawan PT. TNB sebanyak 30 orang yang terdiri dari karyawan tetap dari seluruh departemen. Teknik pengumpulan data dalam penelitian ini menggunakan kuesioner, pengamatan dan dokumentasi dengan instrumen penelitian menggunakan skala likert.

Dalam penelitian ini, menggunakan analisis regresi linier berganda (multiple regression analysis). Berdasarkan hipotesis penelitian ini, untuk menguji dua atau lebih variabel bebas (independent) terhadap satu variabel terikat (dependent), maka menurut Robert D. Mason dan Douglas A. Lind (1999:102), pengujian menggunakan rumus atau persamaan sebagai berikut : 


$$
\mathrm{Y}=\mathrm{a}+\mathrm{b}_{1} \mathrm{X}_{1}+\mathrm{b}_{2} \mathrm{X}_{2}+\mathrm{b}_{3} \mathrm{X}_{3}+\mathrm{e}
$$

\section{HASIL PENELITIAN DAN PEMBAHASAN}

\section{Hasil}

Pada penelitian ini, untuk mengetahui pengaruh variabel Karakteristik Individu $\left(\mathrm{X}_{1}\right)$, Karakteristik Pekerjaan $\left(\mathrm{X}_{2}\right)$, Karakteristik Organisasi $\left(\mathrm{X}_{3}\right)$, sebagai variabel bebas (independent) terhadap Kinerja Karyawan (Y) sebagai variabel terikat (dependent) dilakukan dengan menggunakan analisis regresi linier berganda (multiple regression analysis). Selain itu, dari analisis linear berganda tersebut juga diperoleh koefisien regresi yang menunjukan arah hubungan dari variabel bebas (independent) tersebut dengan variabel terikat (dependent). Berikut hasil pengujian regresi berganda yang disajikan pada tabel 1 dibawah ini :

Tabel 1. Uji Regresi Berganda (uji t)

\begin{tabular}{|c|c|c|c|c|c|}
\hline \multirow[b]{2}{*}{ Model } & \multicolumn{2}{|c|}{$\begin{array}{c}\text { Unstandardized } \\
\text { Coefficients } \\
\text { Std. }\end{array}$} & $\begin{array}{c}\text { Standardized } \\
\text { Coefficients }\end{array}$ & \multirow[b]{2}{*}{$\mathrm{t}$} & \multirow[b]{2}{*}{ Sig. } \\
\hline & $\mathrm{B}$ & Error & Beta & & \\
\hline $1 \quad$ (Constant) & 5,609 & 6,788 & & ,826 & ,416 \\
\hline Karakteristik_Individu &,- 129 &, 111 &,- 167 & $-1,167$ & 254 \\
\hline Karakteristik_Pekerjaan &, 213 &, 100 &, 340 & 2,133 & 043 \\
\hline Karakteristik_Organisasi &, 529 &, 157 & ,566 & 3,364 & ,002 \\
\hline
\end{tabular}

Sumber : Output SPSS, 2018

Berdasarkan hasil perhitungan pada tabel 1. di atas, maka dapat disusun persamaan regresi sebagai berikut :

$\mathrm{Y}=\mathrm{a}+\mathrm{b}_{1} \mathrm{X}_{1}+\mathrm{b}_{2} \mathrm{X}_{2}+\mathrm{b}_{3} \mathrm{X}_{3}+\mathrm{e}$

$5,609-0,129 X_{1}+0,213 X_{2}+0,529 X_{3}+6,788$

Dari persamaan regresi berganda tersebut dapat diinterpretasikan sebagai berikut :

1. Nilai konstanta bernilai positif, hal tersebut menunjukkan jika karakteristik individu, karakteristik pekerjaan dan karakteristik organisasi tidak berubah, maka kinerja karyawan akan memiliki nilai sebesar 5,609.

2. Nilai koefisien regresi karakteristik individu $\left(b_{1}\right)$ sebesar $-0,129$ yang menunjukkan bahwa terdapat arah hubungan yang negatif (tidak searah), artinya, apabila karakteristik individu mengalami kenaikan 1 satuan, maka kinerja karyawan akan berkurang sebesar 0,129 dengan asumsi variabel lainnya dianggap tetap, namun 
kondisi tersebut tidak dapat direpresentasikan, karena hasil pengujian menunjukkan bahwa karakteristik individu tidak memiliki pengaruh yang signifikan.

3. Nilai koefisien regresi karakteristik pekerjaan $\left(b_{2}\right)$ sebesar 0,213 yang menunjukkan bahwa karakteristik pekerjaan arah hubungan yang positif (searah), artinya, apabila karakteristik pekerjaan mengalami kenaikan 1 satuan, maka kinerja karyawan akan meningkat sebesar 0,213 dengan asumsi variabel lainnya dianggap tetap.

4. Nilai koefisien regresi karakteristik organisasi $\left(b_{3}\right)$ sebesar 0,529 yang menunjukkan bahwa terdapat arah hubungan yang positif (searah), artinya apabila karakteristik organisasi mengalami kenaikan 1 satuan, maka kinerja karyawan akan meningkat sebesar 0,529 dengan asumsi variabel lainnya dianggap konstan atau tetap.

\section{Pengaruh Karakteristik Individu secara parsial terhadap Kinerja Karyawan}

Dari hasil uji regresi linier berganda (tabel 1), diperoleh hasil nilai thitung untuk pengaruh karakteristik individu secara parsial terhadap kinerja karyawan sebesar 1,167, sedangkan nilai $t_{\text {tabel }}$ dengan taraf kepercayaan $95 \%(\alpha=0,05)$ diperoleh nilai 2,042 yang mana apabila dibandingkan, nilai thitung lebih kecil dari nilai tabel atau $1,167<2,042$ dengan nilai sig.t sebesar 0,254 yang mana lebih besar dibandingkan 0,05 atau 0,254 > 0,05. Berdasarkan hasil yang diperoleh dari uji regresi linier berganda dengan membandingkan nilai $t_{\text {hitung dan }} t_{\text {tabel }}$ serta nilai sig.t sesuai ketentuan kriteria pengujian dalam penelitian ini, maka dapat dikatakan bahwa tidak terdapat pengaruh signifikan secara parsial karakteristik individu terhadap kinerja karyawan.

\section{Pengaruh Karakteristik Pekerjaan secara parsial terhadap Kinerja Karyawan}

Dari hasil uji regresi linier berganda (tabel 1), diperoleh hasil nilai thitung untuk pengaruh karakteristik pekerjaan secara parsial terhadap kinerja karyawan sebesar 2,133, sedangkan nilai $t_{\text {tabel }}$ dengan taraf kepercayaan $95 \%(\alpha=0,05)$ diperoleh nilai 2,042 yang mana apabila dibandingkan, nilai $t_{\text {hitung }}$ lebih besar dari nilai $t_{\text {tabel }}$ atau 2,133> 2,042 dengan nilai sig.t sebesar 0,043 yang mana lebih kecil dibandingkan 0,05 atau $0,043<0,05$, maka dapat dikatakan bahwa terdapat pengaruh signifikan secara parsial karakteristik pekerjaan terhadap kinerja karyawan PT. TNB. Besar pengaruhnya (nilai Beta) sebesar 0,340 (34\%). 


\section{Pengaruh Karakteristik Organisasi secara parsial terhadap Kinerja Karyawan}

Dari hasil uji regresi linier berganda (tabel 1), diperoleh hasil nilai thitung untuk pengaruh karakteristik organisasi secara parsial terhadap kinerja karyawan sebesar 3,364 , sedangkan nilai tabel dengan taraf kepercayaan 95\% $(\alpha=0,05)$ diperoleh nilai 2,042 yang mana apabila dibandingkan, nilai $t_{\text {hitung }}$ lebih besar dari nilai $t_{\text {tabel }}$ atau 3,364 > 2,042 dengan nilai sig.t sebesar 0,002 yang mana lebih kecil dibandingkan 0,05 atau $0,002<0,05$, maka dapat dikatakan bahwa terdapat pengaruh signifikan secara parsial karakteristik organisasi terhadap kinerja karyawan PT. TNB. Besar pengaruhnya (nilai Beta) sebesar 0,566 (56,6 \%). Hal tersebut juga membuktikan bahwa karakteristik organisasi merupakan variabel yang berpengaruh paling dominan terhadap kinerja karyawan PT. TNB.

\section{Pengaruh Karakteristik Individu, Karakteristik Pekerjaan dan Karakteristik Organisasi secara simultan terhadap Kinerja Karyawan}

Dari hasil uji regresi linier berganda (tabel 2), diperoleh hasil nilai $F_{\text {hitung untuk }}$ pengaruh karakteristik individu, karakteristik pekerjaan dan karakteristik organisasi secara simultan terhadap variabel kinerja karyawan sebesar 11,631, sedangkan nilai $\mathrm{F}_{\text {tabel }}$ dengan taraf kepercayaan $95 \%(\alpha=0,05)$ diperoleh nilai 2,92 yang mana apabila dibandingkan, nilai $F_{\text {hitung }}$ lebih besar dari nilai $F_{\text {tabel }}$ atau 11,631 > 2,92 dengan nilai sig.F sebesar 0,000 yang mana lebih kecil dibandingkan 0,05 atau $0,000<0,05$, maka dapat dikatakan bahwa terdapat pengaruh signifikan secara simultan karakteristik individu, karakteristik dan karakteristik organisasi terhadap kinerja karyawan PT. TNB.

Tabel 2. Uji Regresi Berganda (uji F)

\begin{tabular}{|c|c|c|c|c|c|}
\hline Model & $\begin{array}{c}\text { Sum of } \\
\text { Squares }\end{array}$ & $\mathrm{df}$ & $\begin{array}{l}\text { Mean } \\
\text { Square }\end{array}$ & $F$ & Sig. \\
\hline 1 Regression & 305,914 & 3 & 101,971 & 11,631 &, $000^{\mathrm{b}}$ \\
\hline Residual & 227,953 & 26 & 8,767 & & \\
\hline Total & 533,867 & 29 & & & \\
\hline
\end{tabular}

Sumber : Output SPSS, 2018 
Tabel 3. Nilai $R, R$ Square \& Aj. $R$ Square

\begin{tabular}{llrrr}
\hline Model & $\mathrm{R}$ & R Square & $\begin{array}{c}\text { Adjusted R } \\
\text { Square }\end{array}$ & $\begin{array}{l}\text { Std. Error of } \\
\text { the Estimate }\end{array}$ \\
\hline 1 &, $757^{\mathrm{a}}$ &, 573 &, 524 & 2,961 \\
\hline
\end{tabular}

Sumber : Output SPSS, 2018

Nilai Adjusted $R$ Square menunjukkan 0,524 atau 52,4 \% variabel dari kinerja karyawan PT. TNB dapat dijelaskan oleh variabel dari karakteristik individu, karakteristik pekerjaan, dan karakteristik organisasi, sedangkan selebihnya (100\% $52,4 \%$ ) dijelaskan oleh variabel lain diluar model penelitian.

\section{Pembahasan}

\section{Pengaruh Karakteristik Individu ( $\left.\mathbf{X}_{1}\right)$ terhadap Kinerja Karyawan (Y).}

Hasil uji regresi linier berganda membuktikan bahwa tidak terdapat pengaruh signifikan secara parsial karakteristik individu $\left(\mathrm{X}_{1}\right)$ terhadap kinerja karyawan (Y) PT. TNB ( $\mathrm{H}_{1}$ ditolak), dan memiliki pola kausalitas negatif (tidak searah), artinya apabila dilakukan penambahan nilai pada karakteristik individu, maka kinerja karyawan akan berkurang. Kondisi tersebut tidak dapat direpresentasikan, karena hasil pengujian menunjukkan bahwa karakteristik individu tidak memiliki pengaruh yang signifikan.

Hasil penelitian ini sejalan dengan beberapa penelitian terdahulu diantaranya penelitian oleh Natalia, N. (2011) yang juga mendapatkan hasil bahwa secara parsial tidak terdapat pengaruh signifikan karakteristik individu terhadap kinerja karyawan. Penelitian yang dilakukan Joko, S. (2013) yang membuktikan bahwa tidak terdapat pengaruh signifikan karakteristik individu terhadap kinerja karyawan, namun tidak mendukung hasil penelitian yang dilakukan oleh Sapto, S., dkk. (2010) yang menemukan bahwa karakteristik individu berpengaruh signifikan terhadap kinerja karyawan. Rendi, M, dkk. (2014) yang membuktikan bahwa karakteristik individu memiliki pengaruh positif dan signifikan terhadap prestasi kerja karyawan. Penelitian yang dilakukan Sulastiningsih, dkk. (2014) dan penelitian oleh Destia, A. (2015) yang menemukan hasil yang sama bahwa terdapat pengaruh karakteristik individu terhadap kinerja karyawan secara parsial. 
Hasil penelitian ini mengindikasikan bahwa masih perlunya perhatian pada karakteristik individu yang dapat dilihat dari tanggapan responden terhadap indikator minat yaitu pada butir kesesuaian jabatan/posisi dengan minat yang sebagian besar karyawan PT. TNB menjawab dengan netral. Hal tersebut mendeskripsikan bahwa masih terjadi penempatan posisi/jabatan yang tidak sesuai dengan minat karyawan.

\section{Pengaruh Karakteristik Pekerjaan $\left(\mathbf{X}_{2}\right)$ terhadap Kinerja Karyawan (Y).}

Hasil uji regresi linier berganda membuktikan bahwa terdapat pengaruh signifikan secara parsial karakteristik pekerjaan $\left(\mathrm{X}_{2}\right)$ terhadap kinerja karyawan $(\mathrm{Y})$ PT. TNB $\left(\mathrm{H}_{2}\right.$ diterima), dan memiliki pola kausalitas yang positif (searah) yang menunjukkan bahwa apabila dilakukan peningkatan pada karakteristik pekerjaan (keragaman keterampilan, identitas tugas, signifikasi tugas, otonomi dan umpan balik) yang ada di PT. TNB maka kinerja karyawan akan meningkat, sebaliknya jika karakteristik pekerjaan berkurang, maka akan menurunkan kinerja karyawan PT. TNB.

Hasil penelitian ini memperkuat dan mendukung beberapa penelitian terdahulu diantaranya penelitian oleh Kahya, Emin. (2007) yang membuktikan bahwa terdapat pengaruh yang positif karakteristik pekerjaan terhadap kinerja karyawan yang mana apabila karakteristik pekerjaan baik menghasilkan kinerja karyawan yang meningkat, sebaliknya apabila karakteristik pekerjaan buruk menghasilkan kinerja karyawan menurun. Rendi, M, dkk. (2014) yang membuktikan bahwa karakteristik pekerjaan memiliki pengaruh positif \& signifikan terhadap prestasi kerja karyawan, namun hasil penelitian ini tidak sejalan dengan hasil penelitian oleh Kim, H., Knight, D.K., \& Cruitsinger, C. (2009) dengan hasil temuan yang didapatkan bahwa $\mathrm{H}_{5 \mathrm{a}}$ ditolak $\left(\mathrm{H}_{5 \mathrm{a}}=\right.$ karakteristik pekerjaan berpengaruh positif terhadap kinerja karyawan).

Hasil penelitian ini menunjukkan bahwa karakteristik pekerjaan di PT. TNB dipersepsikan baik dengan butir memberikan manfaat bagi lembaga memiliki nilai rata - rata paling tinggi yang dijawab sebagian besar responden dengan sangat setuju. Hal tersebut mendeskripsikan bahwa tugas/pekerjaan yang diberikan mempunyai manfaat yang besar bagi PT. TNB, namun juga mengindikasikan karakteristik pekerjaan yang masih perlu ditingkatkan, seperti pada indikator umpan 
balik khususnya pada butir diberikan pujian dan diberikan bonus yang sebagian besar dijawab responden dengan tidak setuju. Hal tersebut mendeskripsikan bahwa masih kurangnya perhatian dalam umpan balik yang diterima karyawan atas keberhasilan dalam pekerjaan.

\section{Pengaruh Karakteristik Organisasi ( $\left.\mathbf{X}_{3}\right)$ terhadap Kinerja Karyawan (Y).}

Hasil uji regresi linier berganda membuktikan bahwa terdapat pengaruh signifikan secara parsial karakteristik organisasi $\left(\mathrm{X}_{3}\right)$ terhadap kinerja karyawan $(\mathrm{Y})$ PT. TNB ( $\mathrm{H}_{3}$ diterima), dan memiliki pola kausalitas yang positif (searah) yang menunjukkan bahwa apabila karakteristik organisasi (komitmen organisasi, hubungan dengan sesama rekan kerja dan hubungan dengan atasan) di PT. TNB ditingkatkan maka kinerja karyawan akan meningkat, sebaliknya jika karakteristik organisasi berkurang, maka kinerja karyawan PT. TNB juga akan menurun. Hasil penelitian ini sejalan dengan penelitian yang dilakukan oleh Sapto, S., dkk. (2010) yang membuktikan bahwa karakteristik organisasi berpengaruh signifikan terhadap kinerja karyawan.

Hasil penelitian ini menunjukkan bahwa karakteristik organisasi di PT. TNB dipersepsikan baik dan perlu dipertahankan, seperti yang terlihat pada butir mendukung tercapainya tujuan organisasi memiliki nilai rata - rata paling tinggi yang dijawab sebagian besar responden dengan sangat setuju. Hal tersebut mendeskripsikan bahwa adanya komitmen yang kuat untuk mencapai tujuan PT. TNB yang harus tetap dipertahankan.

\section{Pengaruh Simultan Karakteristik Individu (X1), Karakteristik Pekerjaan $\left(\mathrm{X}_{2}\right)$ Karakteristik Organisasi $\left(\mathbf{X}_{3}\right)$ terhadap Kinerja Karyawan ( $\left.\mathbf{Y}\right)$.}

Hasil uji regresi linier berganda membuktikan karakteristik individu $\left(\mathrm{X}_{1}\right)$, karakteristik pekerjaan $\left(\mathrm{X}_{2}\right)$ dan karakteristik organisasi $\left(\mathrm{X}_{3}\right)$ berpengaruh signifikan secara simultan terhadap kinerja karyawan (Y) PT. TNB dengan koefisien pengaruh secara simultan berbentuk positif (searah) yang menunjukkan bahwa setiap kenaikan nilai dari karakteristik individu, karakteristik pekerjaan, dan karakteristik organisasi secara bersama - sama akan meningkatkan kinerja karyawan, sebaliknya 
turunnya nilai dari karakteristik individu, karakteristik pekerjaan, dan karakteristik organisasi secara bersamaan, maka akan menurunkan kinerja karyawan PT. TNB.

Hasil penelitian ini memperkuat dan mendukung penelitian oleh Rendi, M, dkk. (2014) yang membuktikan bahwa secara simultan variabel karakteristik individu dan karakteristik pekerjaan memiliki pengaruh positif \& signifikan terhadap prestasi kerja karyawan. Penelitian yang dilakukan Sapto, S., dkk. (2010) yang menunjukkan hasil bahwa karakteristik individu, karakteristik organisasi, dan motivasi kerja berpengaruh signifikan terhadap kinerja karyawan baik secara parsial maupun simultan.

\section{KESIMPULAN}

Tujuan penelitian ini adalah untuk menganalisis pengaruh signifikan baik secara parsial maupun simultan karakteristik individu, karakteristik pekerjaan dan karakteristik organisasi terhadap kinerja pegawai Politeknik Kotabaru. Berdasarkan hasil analisis yang dilakukan dalam penelitian ini, maka dapat ditarik kesimpulan bahwa terdapat pengaruh signifikan secara parsial karakteristik pekerjaan, karakteristik organisasi terhadap kinerja karyawan PT. TNB. Namun karakteristik individu tidak memiliki pengaruh signifikan. Sedangkan secara simultan seluruh variabel memiliki pengaruh signifikan terhadap kinerja karyawan PT. TNB.

\section{DAFTAR PUSTAKA}

Ali, S.A.M., Said, N.A., Yunus, N.M., Kader, S.F.A., Latif, D.S.A., \& Munap, R. (2014). Hackman and Oldham's Job Characteristics Model to Job Satisfaction. Procedia - Social and Behavioral Sciences. Vol. 129, p. 46-52.

Arshadi, N., dan Shahbazi, F. (2013). Workplace Characteristics and Turnover Intention : Mediating Role of Emotional Exhaustion. Procedia - Social and Behavioral Sciences. Vol. 84, p. $640-645$.

Banai, Moshe \& Reisel,William D. (2007). The influence of supportive leadership and job characteristics on work alienation: A six-country investigation. Jurnal of World Business. Vol. 42, p. 463 - 476.

José Ramón Cobo-Benita, Enrique Rodríguez-Segura, Isabel Ortiz-Marcos, Luis Ballesteros-Sánchez. (2015). Z Analyzing the impact of organizational characteristics. Journal of Business Research. Vol. xxx, p. xxx - xxx.

Bernardin, J. Dan Russell. (1993). Human Resources Management : an experiental approach. New York: McGraw-Hill Publishing. 
Grotto, Angela R. \& Lyness, Karen S. (2010). The costs of today's jobs: Job characteristics and organizational supports as antecedents of negative spillover. Journal of Vocational Behavior. Vol. 76, p. 395 - 405.

Hauff, S., Richter, N.F., Tressin, T. (2015). Situational job characteristics and job satisfaction: The moderating role of national culture. International Business Review. Vol. xxx, p. xxx - xxx.

Hellregel, Don and Slocum, John. (1996). Manajement, Seventh Editions. Cincinnati Ohio: South Western College Publishing.

Hutchens, Robert. (2010). Worker characteristics, job characteristics, and opportunities for phased retirement. Labour Economics. Vol. 17, p. 1010 1021.

Kahya, Emin. (2007). The effects of job characteristics and working conditions on job performance. International Journal of Industrial Ergonomics. Vol. 37, p. $515-523$.

Kim, H., Knight, D.K., \& Cruitsinger, C. (2009). Generation Y employees' retail work experience: The mediating effect of job characteristics. Journal of Business Research. Vol. 62, p. 548 - 556.

Lee, Jaehee, Lee, Jinjoo, Souder, William E. (2000). Differences of organizational characteristics in new product development: cross-cultural comparison of Korea and the US. Technovation. Vol. 20, p. $497-508$.

McKnight, D.H., Phillips, B., Hardgrave, B.C. (2009). Which reduces IT turnover intention the most: Workplace characteristics or job characteristics?. Information \& Management. Vol. 46, p. 167 - 174.

Moses, R.M., Astuti, E.S., dan Hakam, M.S. (2014). Pengaruh Karakteristik Individu dan Karakteristik Pekerjaan terhadap Prestasi Kerja Karyawan. Jurnal Administrasi Bisnis (JAB). Vol. 12. No. 01, p. 1 - 10.

Ozbag, G.K., Ceyhun, G.C., dan Cekmecelioglu, H.G. (2014). The Moderating Effects of Motivating Job Characteristics on the Relationship between Burnout and Turnover Intention. Procedia - Social and Behavioral Sciences. Vol. 150, p. $438-446$.

Riduan. (2010). Metode dan Teknik Menyusun Tesis, Edisi Kesepuluh. Bandung: ALFABETA

Robert D. Mason dan Douglas A. Lind. (1996). Teknik Statistika untuk Bisnis dan Ekonomi, Edisi Kesembilan. Alih bahasa, Wikarya, U., Soetjipto, W., \& Sugiharso (1999). Jakarta: Erlangga.

Robbins, Stephen. (2006). Perilaku Organisasi, Edisi Kesepuluh. Jakarta: PT. Indeks.

Sugiyono. (2009). Metode Penelitian Kuantitatif, Kualitatif dan Research \& Development. Bandung: Alfabeta.

Tai, C., Chen, L., Chang, C., dan Hong, J. (2012). The impact of individual characteristics, personality traits, perceived risk on young people's intention to 
Volume 4 Nomor 2, Oktober 2018

participate in overseas working holiday. Procedia - Social and Behavioral.Vol.57,p.388-395.

Valter, Moreno, Jr., dan Cavazotte, Flavia. (2015). Using Information System to Leverage Knowledge Management Processes: The Role of Work Context, Job Characteristics and Task- Technology Fit. Procedia Computer Science. Vol. 55 , p. $360-369$. 